The funds needed to create and maintain the Network will be sought from external sources, so that the limited finances now available for the distribution of scientific literature to developing countries will not be reduced.

The immediate objectives of the Network will be:

1) To coordinate information on:

a) organizations that are active in donation programmes,

b) the institutions which they serve, and

c) the materials, especially journals, which they provide,

in order to avoid duplication of efforts and to increase the impact of limited resources;

2) To offer information on appropriate programmes and procedures to organizations and individuals wishing to provide books, journals, or related materials;

3) To explore additional sources of literature;

4) To advise on sources of the funding needed to expand the scope of existing distribution programmes and to launch new ones; and

5) To identify additional needs and opportunities.

Long-term objectives of the Network include:

1. Supporting scientific publishing in the South; and

2. Increasing the distribution to other regions of scientific materials produced in the South.

The network will be coordinated through ICTP/TWAS (Trieste), a pioneer in this field. Membership is open to all interested organizations and institutions.
H.R. DALAFI
International Centre for Theoretical Physics
P.O.B. 586
Miramare
Strade Costiera II
34100 Trieste
Italy.

\title{
Sierra Club's International Activities Directed by Michael McCloskey
}

One of the Sierra Club's long-time executives has changed his position with the organization. Dr J. Michael McCloskey is now the Club's Chairman and is operating out of the Club's Washington, DC, office, which has recently been relocated at $408 \mathrm{C}$ Street Northeast, Washington, DC 20002, USA.

McCloskey served as the Club's Executive Director for 17 years in its San Francisco offices and before then was its Conservation Director. He turned over the job of running the organization on a day-to-day basis to Douglas Wheeler in 1985 , but when Wheeler left unexpectedly in 1986, McCloskey returned to serve a second time in that position until another person, Michael Fischer, could be found to occupy it. Since 1987, McCloskey has been back in Washington in his new capacity.

McCloskey serves as a general spokesman for the Club, maintains wide-ranging contacts with those interested in its work, and is running the Club's Earthcare Network. That Network now embraces over a hundred environmental organizations world-wide which are committed to helping each other on their major campaigns. The Network publishes a newsletter entitled Earthcare Appeals.
Also directed by McCloskey is the Sierra Club's Natural Value Mapping Project, which has just completed a global inventory of the world's main de facto wilderness areas. We wonder privately whether this could form the basis of a World Wilderness Alliance such as we have long advocated-of established and maintained wilderness areas adherents of which would be sufficiently organized at least to get together in defence of any of their counterparts which might be at all seriously threatened in any way.

Currently Dr McCloskey also serves as the Vice-Chairman of the American Committee for International Conservation and as an Adjunct Professor of Policy at the University of Michigan's School of Natural Resources. He is a member of both the law and parks commissions of IUCN, and altogether is an admirably busy executive operating in a number of important directions-including sponsorship of a much-needed World Directory of Environmental Organizations and Institutions which should be usefully complementary to our own planned World Who's Who in Environment \& Conservation: Leading Specialists, Administrators, and Benefactors.

N.P.

\section{New Competition Launched for Conservation Expeditions}

The International Council for Bird Preservation (ICBP) and the Fauna and Flora Preservation Society (FFPS) have established a new competition to stimulate expedition groups to adopt a conservation objective for their work. Expeditions are often in a position to collect useful upto-date information on many aspects of wildlife conservation in parts of the world that are rarely visited by wildlife professionals. ICBP and FFPS also encourage these expeditions, because of their importance in motivating young scientists to become the 'conservationists of tomorrow'.

The competition is a development and extension of the one run by ICBP since 1985 for ornithological expeditions. Since then seven expeditions have received prizes and carried out successful projects leading to significant conservation action. Thus for example 1987 winners visited Pakistan in search of the rare Western Tragopan (Tragopan melanocephalus) which is listed in the Red Data Book as endangered. This is the rarest Himalayan pheasant, with no more than 5,000 individuals left in the wild, and possibly fewer than 1,600 . The team located the pheasants in three valleys in Indus Kohistan and were able to identify their key habitat requirements, the main threats (timber extraction and hunting) to their survival, and potential protected areas. As a result of the expedition, a large-scale project is being developed in collaboration with the National Council for Conservation of Wildlife in Pakistan - to establish protected areas, train Pakistani personnel, and conduct educational and publicity work. One of the two 1988 winning expeditions has just returned from a successful trip to Venezuela, where work was carried out in a little-studied National Park which stimulated interest in its continued protection.

The ICBP/FFPS competition will be open annually henceforth to expeditions consisting of young people-preferably undergraduate students - and taking place in a country outside Europe and North America. The project must 